\title{
The Role of Irisin, Copper and Zinc Levels on Insulin Resistance in Polycystic Ovary Syndrome
}

\author{
Mustafa Bayraktar ${ }^{1}$ \\ Ali Sami Gürbüz ${ }^{2}$ (D) \\ 1 Selcuk University Medical Faculty, Department of Medical Biochemistry, Konya, Turkey. \\ 2 Novafertil IVF Center, Konya, Turkey.
}

Bahadır Öztürk ${ }^{1}$

\begin{abstract}
Background: Polycystic Ovary Syndrome (PCOS) is the most common endocrine disorder in women of reproductive age. Irisin is defined as a myocin released from skeletal muscle that protects individuals from metabolic diseases when exercised regularly. Zinc is thought to play an active role in the pathophysiology of PCOS in relation to insulin resistance. Copper has been stated to contribute to oxidative stress and insulin resistance in PCOS patients. The aim of this study was to evaluate the relationship between serum irisin, copper and zinc levels and insulin resistance in PCOS patients and control cases.

Methods: Our study consists of a patient group of 45 individuals diagnosed with PCOS and a healthy control group of 45 individuals. 2003 Rotterdam diagnostic criteria were used for the diagnosis of PCOS. Serum copper, zinc and irisin levels were measured and evaluated with regard to Body Mass Index and insulin resistance.

Results: Serum zinc and copper levels were found to be higher in PCOS patients compared to controls ( $\mathrm{p}<0.05)$, however no statistically significant differences were found between the groups with regard to HOMA-IR and serum irisin levels.

Conclusions: It was evaluated that the data obtained from the patient group in this study may have been effected due to patients' use of some medications like metformin, multivitamin supplements and oral contraceptives.
\end{abstract}

Key words: PCOS, Irisin, Insulin Resistance, Copper, Zinc.

\section{INTRODUCTION}

Polycystic ovary syndrome (PCOS) is a complex endocrinopathy most prevalent in women of reproductive age with an incidence of approximately 5-10\%. PCOS is a condition characterized by hyperandrogenism, oligomenorrhea, amenorrhea and polycystic ovaries.
Clinical reflection is often in the form of menstrual dysfunction, cosmetic problems, or infertility. PCOS is considered as an important public health issue due to the risks it poses for a long period of time (1-3). PCOS can be defined as a frequent syndrome that is encountered as a result of interaction of complex, environmental and 
genetic factors, although its etiology is not fully known. In the pathophysiology of PCOS, the effects of insulin and its secretion disorders, gonadotropin changes, as well as genetic factors are at the forefront (4-6). Insulin resistance (IR) is believed to play an important role in the pathophysiology of PCOS. Despite numerous clinical and experimental studies, its etiology is still unclear (7, 8). Moreover, IR plays a critical role in the development of metabolic syndrome and cardiovascular diseases in women with PCOS. IR increases susceptibility to long-term dyslipidemia, type 2 diabetes, hypertension, cardiovascular heart diseases (8).

Obesity has attracted attention in recent years as a global public health problem $(9,10)$. Overweight and obese individuals constitute approximately $65 \%$ of the world population. Inadequate energy homeostasis is the main cause of obesity. High energy intake and/or low energy consumption cause inadequate energy homeostasis (11). Obesity negatively affects IR and triggers the risk of diabetes mellitus (DM) and cardiovascular diseases. Considering these, treating obesity should be the primary target for women with PCOS. Thus, long-term health problems may be prevented (12).

Irisin, a protein hormone consisting of 112 amino acids is secreted from adipose tissue (13). Irisin, a thermogenic protein, turns white adipose tissue into brown adipose tissue, thereby causing energy expenditure and is thought to play an important role in reducing fat mass $(11,14)$. Studies have shown that serum irisin level is associated with metabolic diseases including type 2 diabetes, obesity and metabolic syndrome (15). Some cytokine secretions are irregular in PCOS which may be playing a role in IR pathophysiology. The role of irisin in PCOS development is still uncertain. Although human and animal studies suggest a correlation between irisin and obesity and IRrelated metabolic parameters, the results are inconsistent. In particular, the relationship between the circulating irisin and the different features or phenotypes used for the diagnosis of PCOS remains uncertain. It has been stated that more studies are needed to understand the direct relationship between irisin and IR in women with PCOS (16-21).
Zinc is an essential trace element and is necessary for many cellular functions. The role of metalloproteins in the function of inducing members of the hydrolase, ligase, oxidoreductase and lyase family is important. It functions as a cofactor for many enzymes (more than 300) and as a transcription factor in the body. Zinc is involved in many metabolic processes, including carbohydrate, lipid, protein and nucleic acid synthesis and degradation. Zinc deficiency causes many chronic diseases (22-25). Zinc, which is an antioxidant, prevents the formation of free radicals and has a protective role against oxidative stress. Moreover, zinc plays a role in the pathogenesis of rheumatological inflammatory diseases, alcoholism, liver cirrhosis and cardiovascular diseases caused by oxidative damage $(26,27)$. Scientific research shows that plasma zinc levels are low in obese individuals. Zinc deficiency can cause glucose intolerance and insulin resistance (28). Many studies have investigated serum zinc levels in patients with PCOS, but the results of these studies have been insufficient (29). Some studies have demonstrated that serum zinc levels in women with PCOS are higher than healthy women (30). Other studies have reported that circulating zinc levels in women with PCOS are lower $(30-32)$

Copper acts as a biocatalyst in human metabolism and is found in the structure of many metalloenzymes and some natural pigments $(32,33)$. It has been stated in some studies that the increase of oxidative stress may be effective in the pathogenesis of PCOS (34). Copper has been found to induce oxidative stress as a catalyst in the formation of reactive oxygen species while reducing glutathione levels. Copper, which normally binds to proteins, can also be released to perform Fenton-type reactions where hydroxyl radicals are produced. Oxidative stress can also increase due to hyperglycemia, insulin resistance and higher levels of free fatty acids. The induction of oxidative stress causes an increase in the production of reactive oxygen species (35-37).

The aim of this study was to evaluate the relationship between serum irisin, copper and zinc levels and insulin resistance in normal weight, overweight and obese PCOS patients and the control group. 


\section{MATERIALS AND METHODS}

This study was approved by the Selcuk University Medical Faculty Ethics Committee (Date: 08.05.2019, No: $2019 / 114)$ where the study was conducted. The study was explained to the patients and informed written consents were obtained from all participants.

In our study, 16 obese, 10 overweight and 19 normal weight PCOS patients were included in the patient group $(n=45)$ and 12 obese, 14 overweight and 19 normal weight healthy individuals were included in the control group $(n=45)$. A total of 90 individuals were included in our study. For the diagnosis of PCOS, 2003 Rotterdam diagnostic criteria were used. The patients were between 15-44 years old and Body Mass Index (BMI) values were $18.5-40 \mathrm{~kg} / \mathrm{m} 2$. Overweight is defined as a BMI of 25-29.9 $\mathrm{kg} / \mathrm{m}^{2}$, while a BMI $\geq 30 \mathrm{~kg} / \mathrm{m}^{2}$ defines obesity. If BMI was below $25 \mathrm{~kg} / \mathrm{m}^{2}$, it was considered normal weight. Patients included in the study did not have accompanying chronic diseases. Patients with previously diagnosed Cushing's disease, hypertension and cardiovascular diseases were not included in the study. Serum copper and zinc levels were measured by an Atomic Absorption Spectrometer (Varian AA240FS), serum irisin levels were measured by a commercial ELISA kit (Elabscience, Catalog No: E-EL-H6120). Glucose and insulin measurements were done with routinely used methods. Insulin resistance was estimated by homeostasis model assessment of insulin resistance (HOMA-IR). HOMA-IR was calculated according to the following formula: [Fasting insulin $(\mu \mathrm{U} /$ $\mathrm{ml}) X$ fasting glucose $(\mathrm{mg} / \mathrm{dl})]$ / 405. BMI values $(\mathrm{kg} / \mathrm{m} 2)$ were calculated as the ratio of the body weight $(\mathrm{kg})$ to the height squared (m2).

\section{STATISTICAL ANALYSIS}

Data were analyzed by using statistical SPSS 25 software (IBM Corp. Released 2017. IBM SPSS Statistics for Windows, Version 25.0. Armonk, NY: IBM Corp). The homogeneity of variances was checked with the "Levene test". The distribution of the variables was analyzed with the "Shapiro-Wilk test". "Independent Student's t-test" was used for comparing differences of normally distributed variables between two groups. Mann Whitney
U test was used for non-parametric distributed values. Data were presented as mean \pm standard deviation (SD) for normally distributed variables. Correlation analysis was carried out with Pearson's and Spearman's correlation tests. " $\mathrm{p}$ " values lower than $<0.05$ was considered to be statistically significant.

\section{RESULTS}

In our study, a statistically significant difference was found with regard to serum zinc and serum copper levels in PCOS patients compared to the control group ( $\mathrm{p}<0.05$ ). Serum zinc and serum copper levels were found to be higher in patients with PCOS compared to individuals in the control group (Table 1).

Table 1. Comparison of Parameters in Patient and Control Groups.

\begin{tabular}{|c|c|c|c|}
\hline Parameter & $\begin{array}{c}\text { Patient Group } \\
(\mathbf{n}=45) \\
(\text { Mean } \pm \text { SD })\end{array}$ & $\begin{array}{c}\text { Control Group } \\
(\mathbf{n}=45) \\
(\text { Mean } \pm \text { SD })\end{array}$ & $\mathrm{p}$ \\
\hline $\begin{array}{c}\text { Irisin } \\
(\mathrm{pg} / \mathrm{ml})\end{array}$ & $191.48 \pm 180.97$ & $237.32 \pm 221.54$ & 0.327 \\
\hline $\begin{array}{c}\text { Zinc } \\
(\mu \mathrm{mol} / \mathrm{L})\end{array}$ & $15.90 \pm 3.45$ & $13.34 \pm 3.58$ & $\mathbf{0 . 0 0 1}$ \\
\hline $\begin{array}{c}\text { Copper } \\
(\mu \mathrm{g} / \mathrm{dL})\end{array}$ & $147.72 \pm 40.28$ & $118.13 \pm 41.65$ & $\mathbf{0 . 0 0 1}$ \\
\hline $\begin{array}{c}\text { Glucose } \\
(\mathrm{mg} / \mathrm{dl})\end{array}$ & $81.98 \pm 13.39$ & $83.58 \pm 14.08$ & 0.805 \\
\hline $\begin{array}{c}\text { Insulin } \\
(\mu \mathrm{U} / \mathrm{mL})\end{array}$ & $9.75 \pm 4.28$ & $8.99 \pm 3.65$ & 0.369 \\
\hline HOMA-IR & $2.02 \pm 1.0$ & $1.9 \pm 0.95$ & 0.580 \\
\hline
\end{tabular}

Homa-IR: homeostasis model assessment of insulin resistance

According to the results obtained in the study, negative correlation between copper and irisin $(\mathrm{r}:-0,215, \mathrm{p}<0.05)$ and positive correlation between zinc and copper ( $\mathrm{r}: 0,483$, $\mathrm{p}<0.01)$ were found. There was a negative correlation between insulin and irisin ( $\mathrm{r}$ : $-0,235, \mathrm{p}<0.05)$; positive correlation between glucose and insulin ( $\mathrm{r}: 0,320, \mathrm{p}<0.01)$, negative correlation between HOMA-IR and irisin (r: $-0,241, \mathrm{p}<0.05)$; positive correlation between glucose and HOMA-IR ( $\mathrm{r}: 0,593, \mathrm{p}<0.01)$ were observed. A positive correlation between insulin and HOMA-IR ( $\mathrm{r}$ : 0,938, $\mathrm{p}<0.01$ ) was also identified (Table 2). 
Table 2. Correlation analysis results between all variables for all patients

\begin{tabular}{|c|c|c|c|c|c|c|}
\hline \multicolumn{2}{|l|}{$\mathrm{n}=90$} & $\begin{array}{l}\text { Irisin } \\
(\mathrm{pg} / \mathrm{ml})\end{array}$ & Zinc $(\mu \mathrm{mol} / \mathrm{L})$ & $\begin{array}{l}\text { Copper }(\mu \mathrm{g} / \\
\mathrm{dL})\end{array}$ & $\begin{array}{l}\text { Glucose (mg/ } \\
\text { dl) }\end{array}$ & $\begin{array}{l}\text { Insulin } \\
(\mu \mathrm{U} / \mathrm{mL})\end{array}$ \\
\hline \multirow{2}{*}{ Zinc $(\mu \mathrm{mol} / \mathrm{L})$} & $\mathrm{r}$ & -0.123 & & & & \\
\hline & $\mathrm{p}$ & 0.246 & & & & \\
\hline \multirow{2}{*}{$\begin{array}{l}\text { Copper } \\
(\mu \mathrm{g} / \mathrm{dL})\end{array}$} & $\mathrm{r}$ & $-.215^{*}$ & $.483^{* *}$ & & & \\
\hline & $\mathrm{p}$ & 0.042 & 0.001 & & & \\
\hline \multirow{2}{*}{ Glucose (mg/dL) } & $\mathrm{r}$ & -0.122 & -0.003 & 0.115 & & \\
\hline & $\mathrm{p}$ & 0.251 & 0.975 & 0.279 & & \\
\hline \multirow{2}{*}{$\begin{array}{l}\text { Insulin } \\
(\mu \mathrm{U} / \mathrm{mL})\end{array}$} & $\mathrm{r}$ & $-.235^{*}$ & -0.007 & 0.161 & $.320^{* *}$ & \\
\hline & $\mathrm{p}$ & 0.026 & 0.946 & 0.130 & 0.002 & \\
\hline \multirow{2}{*}{ HOMA-IR } & $\mathrm{r}$ & $-.241^{*}$ & -0.007 & 0.157 & $.593^{* *}$ & $.938^{* *}$ \\
\hline & $\mathrm{p}$ & 0.022 & 0.946 & 0.140 & 0.001 & 0.001 \\
\hline
\end{tabular}

${ }^{*} \mathrm{p}<0.05 .{ }^{* *} \mathrm{p}<0.01$.

When obese individuals in the PCOS and control groups were compared, a statistically significant difference between serum zinc and serum copper levels were found $(\mathrm{p}<0.05)$. Serum zinc and serum copper values were higher in obese individuals with PCOS than those in the control group (Table 3).

Table 3. Comparison of parameters in obese patients and controls.

\begin{tabular}{|c|c|c|c|}
\hline Parameter & $\begin{array}{c}\text { Obese Patient } \\
\text { Group (n=16) } \\
\text { Mean } \pm \text { SD }\end{array}$ & $\begin{array}{c}\text { Obese Control } \\
\text { Group (n=12) } \\
\text { Mean } \pm \text { SD }\end{array}$ & $\mathbf{p}$ \\
\hline $\begin{array}{c}\text { Irisin } \\
(\mathrm{pg} / \mathrm{ml})\end{array}$ & 194.75244 .5 & 107.869 .31 & 0.486 \\
\hline $\begin{array}{c}\text { Zinc } \\
(\mu \mathrm{mol} / \mathrm{L})\end{array}$ & 16.694 .17 & 10.953 .39 & $\mathbf{0 . 0 0 1}$ \\
\hline $\begin{array}{c}\text { Copper } \\
(\mu \mathrm{g} / \mathrm{dL})\end{array}$ & 141.5333 .53 & 93.5832 .47 & $\mathbf{0 . 0 0 1}$ \\
\hline $\begin{array}{c}\text { Glucose } \\
(\mathrm{mg} / \mathrm{dl})\end{array}$ & 85.1312 .92 & 94.017 .33 & 0.226 \\
\hline $\begin{array}{c}\text { Insulin } \\
(\mu \mathrm{U} / \mathrm{mL})\end{array}$ & 13.333 .73 & 11.953 .75 & 0.345 \\
\hline HOMA-IR & 2.841 .00 & 2.791 .03 & 0.898 \\
\hline
\end{tabular}

According to the results obtained in obese PCOS patients and control individuals, positive correlation between copper and zinc $(\mathrm{r}: 0,644, \mathrm{p}<0.01)$, positive correlation between insulin and copper ( $\mathrm{r}: 0,432, \mathrm{p}<0.05)$, positive correlation between HOMA-IR and copper (r: 0,391, $\mathrm{p}<0.05)$, positive correlation between glucose and HOMAIR ( $\mathrm{r}: 0,591, \mathrm{p}<0.01)$, and positive correlation between insulin and HOMA-IR (r: 0,881, p<0.01) were observed (Table 4).

Table 4. Correlation analysis results between all variables for obese individuals

\begin{tabular}{|c|c|c|c|c|c|c|}
\hline $\mathrm{n}=\mathbf{2 8}$ & & $\begin{array}{l}\text { Irisin } \\
\text { (pg/ml) }\end{array}$ & $\begin{array}{c}\text { Zinc } \\
(\mu \mathrm{mol} \\
/ \mathrm{L})\end{array}$ & $\begin{array}{l}\text { Copper } \\
(\mu \mathrm{g} / \mathrm{dL})\end{array}$ & $\begin{array}{l}\text { Glucose } \\
\text { (mg/dl) }\end{array}$ & $\begin{array}{c}\text { Insulin } \\
(\mu \mathrm{U} /\end{array}$ \\
\hline Zinc & $\mathrm{r}$ & -.086 & & & & \\
\hline$(\mu \mathrm{mol} / \mathrm{L})$ & $\mathrm{p}$ & .662 & & & & \\
\hline Copper & $\mathrm{r}$ & .118 & $.644^{* *}$ & & & \\
\hline$(\mu \mathrm{g} / \mathrm{dL})$ & $\mathrm{p}$ & .551 & .001 & & & \\
\hline Glucose & $\mathrm{r}$ & -.124 & .054 & .148 & & \\
\hline$(\mathrm{mg} / \mathrm{dl})$ & $\mathrm{p}$ & .528 & .786 & .451 & & \\
\hline Insulin & $r$ & .139 & -.023 & $.432^{*}$ & .164 & \\
\hline $\begin{array}{c}(\mu \mathrm{U} / \\
\mathrm{mL})\end{array}$ & $\mathrm{p}$ & .482 & .909 & .022 & .403 & \\
\hline $\mathrm{HO}-$ & $r$ & .067 & .008 & $.391^{*}$ & $.591^{* *}$ & $.881^{* *}$ \\
\hline MA-IR & $\mathrm{p}$ & .734 & .967 & .040 & .001 & .001 \\
\hline
\end{tabular}

${ }^{*} \mathrm{p}<0.05$. ${ }^{* *} \mathrm{p}<0.01$.

When overweight individuals in the PCOS and control groups were compared with regard to all parameters, there was no statistically significant difference between the two groups. 
According to the results we obtained in overweight PCOS patients and control individuals, a positive correlation between insulin and copper $(\mathrm{r}: 0,434, \mathrm{p}<0.05)$, HOMA-IR and glucose (r: 0,606, p<0.01), and insulin and HOMA-IR ( $\mathrm{r}: 0,949, \mathrm{p}<0.01)$ were observed (Table 5).

Table 5. Correlation analysis results between all variables for overweight individuals

\begin{tabular}{|c|c|c|c|c|c|c|}
\hline \multicolumn{2}{|l|}{$\mathrm{n}=24$} & $\begin{array}{c}\text { Irisin } \\
\text { (pg/ } \\
\mathrm{ml})\end{array}$ & $\begin{array}{c}\text { Zinc } \\
(\mu \mathrm{mol} / \\
\mathrm{L})\end{array}$ & $\begin{array}{l}\text { Copper } \\
(\mu \mathrm{g} / \mathrm{dL})\end{array}$ & $\begin{array}{l}\text { Glucose } \\
\text { (mg/dl) }\end{array}$ & $\begin{array}{l}\text { Insulin } \\
\text { ( } \mu \mathrm{U} / \\
\text { mL) }\end{array}$ \\
\hline \multirow{2}{*}{$\begin{array}{c}\text { Zinc } \\
(\mu \mathrm{mol} / \mathrm{L})\end{array}$} & $r$ & .146 & & & & \\
\hline & $\mathrm{p}$ & .495 & & & & \\
\hline \multirow{2}{*}{$\begin{array}{l}\text { Copper } \\
(\mu \mathrm{g} / \mathrm{dL})\end{array}$} & $\mathrm{r}$ & -.024 & -.075 & & & \\
\hline & $\mathrm{p}$ & .911 & .728 & & & \\
\hline \multirow{2}{*}{$\begin{array}{l}\text { Glucose } \\
(\mathrm{mg} / \mathrm{dl})\end{array}$} & $r$ & .221 & -.106 & .086 & & \\
\hline & $\mathrm{p}$ & .300 & .622 & .691 & & \\
\hline \multirow{2}{*}{$\begin{array}{l}\text { Insulin } \\
(\mu \mathrm{U} / \mathrm{mL})\end{array}$} & $r$ & -.206 & -.093 & $.434^{*}$ & .357 & \\
\hline & $\mathrm{p}$ & .333 & .665 & .034 & .087 & \\
\hline \multirow{2}{*}{$\begin{array}{c}\text { HO- } \\
\text { MA-IR }\end{array}$} & $r$ & -.124 & -.091 & .355 & $.606^{* *}$ & $.949^{* *}$ \\
\hline & $\mathrm{p}$ & .563 & .671 & .089 & .002 & .001 \\
\hline
\end{tabular}

${ }^{*} \mathrm{p}<0.05$. ${ }^{* *} \mathrm{p}<0.01$.

When normal-weight PCOS patients and control individuals were compared, a statistically significant difference in serum copper levels were determined ( $p$ $<0.05)$. Serum copper values were found to be higher in PCOS patients compared to controls (Table 6).
Table 6. Comparison of parameters in normal-weight patients and controls.

\begin{tabular}{|c|c|c|c|}
\hline Parameter & $\begin{array}{c}\text { Normal Weight } \\
\text { Patient Group } \\
(\mathbf{n}=19) \\
\text { Mean } \pm \text { SD }\end{array}$ & $\begin{array}{c}\text { Normal Weight } \\
\text { Control Group } \\
(\mathbf{n}=19) \\
\text { Mean } \pm \text { SD }\end{array}$ & $\mathbf{p}$ \\
\hline $\begin{array}{c}\text { Irisin } \\
(\mathrm{pg} / \mathrm{ml})\end{array}$ & 178.01140 .28 & 289.79245 .9 & 0.204 \\
\hline $\begin{array}{c}\text { Zinc } \\
(\mu \mathrm{mol} / \mathrm{L})\end{array}$ & 15.283 .03 & 13.493 .18 & 0.084 \\
\hline $\begin{array}{c}\text { Copper } \\
(\mu \mathrm{g} / \mathrm{dL})\end{array}$ & 163.3445 .80 & 117.6348 .57 & $\mathbf{0 . 0 0 5}$ \\
\hline $\begin{array}{c}\text { Glucose } \\
(\mathrm{mg} / \mathrm{dl})\end{array}$ & 81.1113 .28 & 80.4710 .45 & 0.871 \\
\hline $\begin{array}{c}\text { Insulin } \\
(\mu \mathrm{U} / \mathrm{mL})\end{array}$ & 7.693 .15 & 7.543 .18 & 0.99 \\
\hline $\mathrm{HOMA}-\mathrm{IR}$ & 1.570 .63 & 1.520 .73 & 0.805 \\
\hline
\end{tabular}

According to the results obtained in patients with normalweight PCOS and control individuals, negative correlation between zinc and irisin ( $\mathrm{r}$ : -0,389, $\mathrm{p}<0.05$ ), negative correlation between copper and irisin $(\mathrm{r}:-0,546, \mathrm{p}<0.01)$; positive correlation between zinc and copper ( $\mathrm{r}: 0,592$, $\mathrm{p}<0.01$ ), negative correlation between insulin and irisin ( $\mathrm{r}:-0,379, \mathrm{p}<0.01)$, negative correlation between HOMAIR and irisin ( $\mathrm{r}:-0,433, \mathrm{p}<0.01)$, positive correlation between copper and HOMA-IR (r: 0,335, p<0.05), positive correlation between glucose and HOMA-IR (r: 0,435, $\mathrm{p}<0.01)$ and positive correlation between insulin and HOMA-IR (r: 0,926, p<0.01) were observed (Table 7).

Table 7. Correlation analysis results between all variables for normal-weight individuals

\begin{tabular}{|c|c|c|c|c|c|c|}
\hline \multicolumn{2}{|l|}{$\mathrm{n}=38$} & $\begin{array}{l}\text { İrisin } \\
(\mathrm{pg} / \mathrm{mL})\end{array}$ & $\begin{array}{c}\text { Zinc } \\
(\mu \mathrm{mol} / \mathrm{L})\end{array}$ & $\begin{array}{l}\text { Copper } \\
(\mu \mathrm{g} / \mathrm{dL})\end{array}$ & $\begin{array}{l}\text { Glucose (mg/ } \\
\text { dl) }\end{array}$ & $\begin{array}{c}\text { Insulin }(\mu \mathrm{U} / \\
\mathrm{mL})\end{array}$ \\
\hline \multirow{2}{*}{$\begin{array}{c}\text { Zinc } \\
(\mu \mathrm{mol} / \mathrm{L})\end{array}$} & $\mathrm{r}$ & $-.389^{*}$ & & & & \\
\hline & $\mathrm{p}$ & .016 & & & & \\
\hline \multirow{2}{*}{$\begin{array}{l}\text { Copper } \\
(\mu \mathrm{g} / \mathrm{dL})\end{array}$} & $\mathrm{r}$ & $-.546^{* *}$ & $.592^{* *}$ & & & \\
\hline & $\mathrm{p}$ & .001 & .001 & & & \\
\hline \multirow{2}{*}{$\begin{array}{l}\text { Glucose } \\
(\mathrm{mg} / \mathrm{dl})\end{array}$} & $\mathrm{r}$ & -.205 & .074 & .254 & & \\
\hline & $\mathrm{p}$ & .217 & .659 & .124 & & \\
\hline \multirow{2}{*}{$\begin{array}{l}\text { İnsulin } \\
(\mu \mathrm{U} / \mathrm{mL})\end{array}$} & $\mathrm{r}$ & $-.379^{*}$ & .177 & .263 & .122 & \\
\hline & $\mathrm{p}$ & .019 & .287 & .111 & .464 & \\
\hline \multirow{2}{*}{ HOMA-IR } & $\mathrm{r}$ & $-.433^{* *}$ & .171 & $.335^{*}$ & $.435^{* *}$ & $.926^{* *}$ \\
\hline & $\mathrm{p}$ & .007 & .305 & .040 & .006 & .001 \\
\hline
\end{tabular}

${ }^{*} \mathrm{p}<0.05$. ${ }^{* *} \mathrm{p}<0.01$. 


\section{DISCUSSION}

PCOS, although its etiology is not fully known, can be defined as a frequently encountered syndrome that occurs as a result of the interaction of complex, environmental and genetic factors. In the pathophysiology of PCOS, the effects of insulin and its secretion disorders, gonadotropin changes, as well as genetic elements are considered very important $(5,6)$

Irisin is a cleavage protein of fibronectin type III domain 5 (FND5). It significantly reduces activity in skeletal muscles in women with PCOS. In a meta-analysis by Wang et al., irisin levels were found to be higher in PCOS patients than in control individuals, but they did not report a significant correlation between circulating irisin levels and IR in their population (18). In the studies by Gao et al. and Pukajło et al., no significant difference with regard to serum irisin levels were found between PCOS patients and control individuals $(19,20)$. In our study, serum irisin levels of patients with PCOS were lower than the control group (the difference was not statistically significant). There was also a negative correlation between insulin and HOMA-IR, and irisin levels. Serum irisin levels of obese PCOS patients were higher than the obese control group (the difference was not statistically significant). Serum irisin levels in normal-weight PCOS patients were lower than control group participants (the difference was not statistically significant). A negative correlation was observed between HOMA-IR and irisin. In women with PCOS, the function of the receptor-gamma coactivator 1 alpha (PGC 1-a), which is activated by degraded peroxisome proliferator is considerably repressed. This leads to changes in the expression and function of irisin. The (statistically nonsignificant) low irisin levels in PCOS patients observed in this study are thought to be caused by the repression of PGC-1a.

Copper $(\mathrm{Cu})$ acts as a biocatalyst in human metabolism and is found in the structure of many metalloenzymes and some natural pigments (32). It has been reported in some studies that an increase in oxidative stress levels may play a role in the pathogenesis of PCOS (38). In the studies by Kurdoğlu et al., Kanafchian et al. and Celik et al. serum $\mathrm{Cu}$ levels of PCOS patients were found to be significantly higher than the control group (36). High $\mathrm{Cu}$ levels have been shown to be associated with an increased risk of early cardiovascular diseases $(36,37,39)$. In the present study, serum $\mathrm{Cu}$ levels were higher in PCOS patients than in the control group. $\mathrm{Cu}$ levels were found to be higher in PCOS patients regardless of BMI. A positive and statistically significant correlation was found between HOMA-IR and $\mathrm{Cu}$. Increased IR may cause increased oxidative stress, which may lead to increased $\mathrm{Cu}$ levels in individuals with PCOS. Further studies that include reactive oxygen species as a parameter may be useful in order to clarify the relationship between high $\mathrm{Cu}$ levels in PCOS patients.

Zinc $(\mathrm{Zn})$ is an essential trace element that is fundamental for many cellular functions. $\mathrm{Zn}$ is involved in many metabolic processes, including carbohydrate, lipid, protein and nucleic acid synthesis and degradation. Zn deficiency causes many chronic diseases $(22,36,39)$. In a study conducted by Kurdoğlu et al, zinc levels of PCOS patients were found higher than the control individuals. However, these values remained within the reference range $(10,7-$ $17,5 \mu \mathrm{mol} / \mathrm{L}$ ) (39). In the study conducted by Chakraborty et al, although zinc levels of PCOS patients were higher than the control individuals, no statistically difference was found (32). In a study by Kulhan et al. values also remained within the reference range $(10,7-17,5 \mu \mathrm{mol} / \mathrm{L})$. In another study by Kanafchian et al. significantly lower results were found in patients with PCOS compared to the control group $(30,31)$. In the present study, serum zinc levels were higher in PCOS patients compared to the control group. In addition, zinc levels in obese PCOS patients were higher than the obese individuals in the control group and there was a statistically significant difference which remained in the reference range $(10.7-17.5 \mu \mathrm{mol} / \mathrm{L})$. No relationship was found between HOMA-IR and zinc levels. The higher zinc levels may be specific to women in Turkey as an ethnic difference. Serum zinc levels being in the reference range may be the reason for HOMA-IR and zinc levels not to be correlated.

In conclusion, serum $\mathrm{Zn}$ and $\mathrm{Cu}$ levels were found to be higher in PCOS patients compared to controls, however no statistically significant differences were found between the groups with regard to HOMA-IR and serum irisin levels. Data obtained from the patient group in this study may have been effected due to their use of some medications like metformin, multivitamin supplements and oral contraceptives.

Further studies with higher number of participants may improve the distinction of the variables like irisin and HOMA-IR between the PCOS patients and controls. 


\section{Declarations}

This research was supported by Scientific Research Projects of Selcuk University with project number 19202059.

There is no conflict of interest.

This study was approved by the Selcuk University Medical Faculty Ethics Committee (Date: 08.05.2019, No: 2019/114) where the study was conducted. The study was explained to the patients and informed written consents were obtained from all participants.

\section{REFERENCES}

1. Di Pietro M, Pascuali N, Parborell F, Abramovich D. Ovarian angiogenesis in polycystic ovary syndrome. Reproduction. 2018;155(5):R199-R209.

2. Speroff L, Fritz MA. Clinical gynecologic endocrinology and infertility. 7th ed. Philadelphia, USA: lippincott Williams \& wilkins; 2005.

3. Shannon M, Wang Y. Polycystic ovary syndrome: a common but often unrecognized condition. Journal of midwifery \& women's health. 2012;57(3):221-30

4. Baysal B. Polikistik over sendromu ve hirsutizm. İÜ Cerrahpaşa Tıp Fakültesi Sürekli Tıp Eğitimi Etkinlikleri Sempozyum Dizisi2008. p. 99-107.

5. Rosenfield RL, Ehrmann DA. The pathogenesis of polycystic ovary syndrome (PCOS): the hypothesis of PCOS as functional ovarian hyperandrogenism revisited. Endocrine reviews. 2016;37(5):467-520.

6. Evliyaoglu O. Polycystic ovary syndrome and hirsutism/Polikistik over sendromu ve hirsutizm. J Turkish Pediatrics Archive. 2011:S97-S.

7. Vrbíková J, Bendlová B, Hill M, Vanková M, Vondra K, Stárka L. Insulin sensitivity and $\beta$-cell function in women with polycystic ovary syndrome. J Diabetes Care. 2002;25(7):1217-22.

8. Kucur SK, Yüksel B, Seven A, Polat M, Keskin N, Aksoy AN. Farklı Dört Polikistik Over Sendromu Fenotipinin Klinik Ve Laboratuvar Değerlerinin Karşılaştırılması. J Mustafa Kemal Üniversitesi Tıp Dergisi. 2016;7(26).

9. Şahin SB, Sümer F, Sezgin H, Ayaz T, Şahin OZ, İlkkılıç K, et al. Polikistik over sendromlu hastalarda obezitenin klinik, metabolik ve hormonal özellikler üzerine etkisi. J Journal of Clinical Experimental Investigations. 2014;5(4):567-71.

10. Diamanti-Kandarakis E. Role of obesity and adiposity in polycystic ovary syndrome. J International journal of obesity. 2007;31(2):S8-S13.

11. Aslan NN, Yardımcı H. Obezite üzerine etkili yeni bir hormon: İrisin. Gümüşhane Üniversitesi Sağlık Bilimleri Dergisi. 2017;6(3):176-83.

12. Salley KE, Wickham EP, Cheang KI, Essah PA, Karjane NW, Nestler JE. Position statement: glucose intolerance in polycystic ovary syndrome-a position statement of the Androgen Excess Society. The Journal of Clinical Endocrinology Metabolism. 2007;92(12):4546-56.
13. Boström P, Wu J, Jedrychowski MP, Korde A, Ye L, Lo JC, et al. A PGC1- $\alpha$-dependent myokine that drives brown-fat-like development of white fat and thermogenesis. Nature. 2012;481(7382):463-8.

14. Aydin S. Three new players in energy regulation: preptin, adropin and irisin. Peptides. 2014;56:94-110.

15. Masaeli A, Nayeri H, Mirzaee M. Effect of metformin treatment on insulin resistance markers, and circulating irisin in women with polycystic ovarian syndrome (PCOS). Hormone Metabolic Research. 2019;51(09):575-9.

16. Abali R, Temel Yuksel I, Yuksel MA, Bulut B, Imamoglu M, Emirdar $\mathrm{V}$, et al. Implications of circulating irisin and Fabp4 levels in patients with polycystic ovary syndrome. Journal of Obstetrics Gynaecology. 2016;36(7):897-901.

17. Zhang L, Fang X, Li L, Liu R, Zhang C, Liu H, et al. The association between circulating irisin levels and different phenotypes of polycystic ovary syndrome. Journal of endocrinological investigation. 2018;41(12):1401-7.

18. Wang C, Zhang X-Y, Sun Y, Hou X-G, Chen LJGE. Higher circulating irisin levels in patients with polycystic ovary syndrome: a metaanalysis. Gynecological Endocrinology. 2018;34(4):290-3

19. Pukajło K, Łaczmański Ł, Kolackov K, Kuliczkowska-Płaksej J Bolanowski M, Milewicz A, et al. Irisin plasma concentration in PCOS and healthy subjects is related to body fat content and android fat distribution. Gynecological Endocrinology. 2015;31(11):907-11.

20. Gao S, Cheng Y, Zhao L, Chen Y, Liu Y. The relationships of irisin with bone mineral density and body composition in PCOS patients. Diabetes/metabolism research reviews. 2016;32(4):421-8.

21. Qiu S, Cai X, Yin H, Zügel M, Sun Z, Steinacker JM, et al. Association between circulating irisin and insulin resistance in non-diabetic adults: a meta-analysis. Metabolism. 2016;65(6):825-34.

22. Cai L, Li X, Song Y, Cherian M. Essentiality and Toxicology of Zinc and Copper and its chelation therapy. Current Medicinal Chemistry. 2005; 12.23:2753-63.

23. Vallee BL, Falchuk KH. The biochemical basis of zinc physiology. Physiological reviews. 1993;73(1):79-118.

24. Coleman JEJArob. Zinc proteins: enzymes, storage proteins, transcription factors, and replication proteins. Annual review of biochemistry. 1992;61:897-946.

25. Maktabi M, Jamilian, M., \& Asemi, Z. . Magnesium-zinc-calciumvitamin $\mathrm{D}$ co-supplementation improves hormonal profiles, biomarkers of inflammation and oxidative stress in women with polycystic ovary syndrome: a randomized, double-blind, placebocontrolled trial. Biological trace element research, . 2018;182(1):21-8.

26. Belviranli M, Okudan N, Karakuyu N. The association between irisin levels, element distribution and oxidative stress markers in adolescent swimmers. Hormone molecular biology clinical investigation. 2018;34(3).

27. Hess SY, Lönnerdal B, Hotz C, Rivera JA, Brown KH. Recent advances in knowledge of zinc nutrition and human health. Food nutrition bulletin. 2009;30(1_suppl1):S5-S11. 
28. Kim J, Lee S. Effect of zinc supplementation on insulin resistance and metabolic risk factors in obese Korean women. Nutrition research practice. 2012;6(3):221-5.

29. Abedini M, Ghaedi E, Hadi A, Mohammadi H, Amani R. Zinc status and polycystic ovarian syndrome: A systematic review and metaanalysis. Journal of Trace Elements in Medicine Biology. 2019;52:216-21.

30. Kanafchian M, Mahjoub S, Esmaeilzadeh S, Rahsepar M, Mosapour A. Status of serum selenium and zinc in patients with the polycystic ovary syndrome with and without insulin resistance. Middle East Fertility Society Journal. 2018;23(3):241-5.

31. Kulhan M, Kulhan NG, Nayki UA, Nayki C, Ata N, Ulug P, et al. Assessment of the relationship between serum vitamin (A, B 12, C, $\mathrm{D}$, folate) and zinc levels and polycystic ovary syndrome. Archives of Medical Science-Civilization Diseases. 2017;2(1):62-9.

32. Chakraborty P, Ghosh S, Goswami S, Kabir SN, Chakravarty B, Jana K. Altered trace mineral milieu might play an aetiological role in the pathogenesis of polycystic ovary syndrome. Biological trace element research. 2013;152(1):9-15.

33. Janet Y. Uriu-Adams CLK. Copper, oxidative stress, and human health. Molecular Aspects of Medicine. 2008;26:268-98.

34. Kurdoglu Z OH, Tuluce $\mathrm{Y}$, Koyuncu. Oxidative status and its relation with insulin resistance in young non-obese women with polycystic ovary syndrome. Journal of Endocrinological Investigation. 2012;35(3):317-21.

35. Mahjoub S, \& Masrour-Roudsari, J. Role of oxidative stress in pathogenesis of metabolic syndrome. . Caspian journal of internal medicine. 2012;3.1386

36. Celik C, Bastu E, Abali R, Alpsoy S, Guzel EC, Aydemir B, et al. The relationship between copper, homocysteine and early vascular disease in lean women with polycystic ovary syndrome. Gynecological Endocrinology. 2013;29(5):488-91.

37. Kanafchian M, Esmaeilzadeh S, Mahjoub S, Rahsepar M, Ghasemi M. Status of serum copper, magnesium, and total antioxidant capacity in patients with polycystic ovary syndrome. Biological Trace Element Research. 2020;193(1):111-7.

38. Fenkci V, Fenkci S, Yilmazer M, Serteser M. Decreased total antioxidant status and increased oxidative stress in women with polycystic ovary syndrome may contribute to the risk of cardiovascular disease. Fertility sterility. 2003;80(1):123-7.

39. Kurdoglu Z, Kurdoglu M, Demir H, Sahin H. Serum trace elements and heavy metals in polycystic ovary syndrome. Human experimental toxicology. 2012;31(5):452-6. 